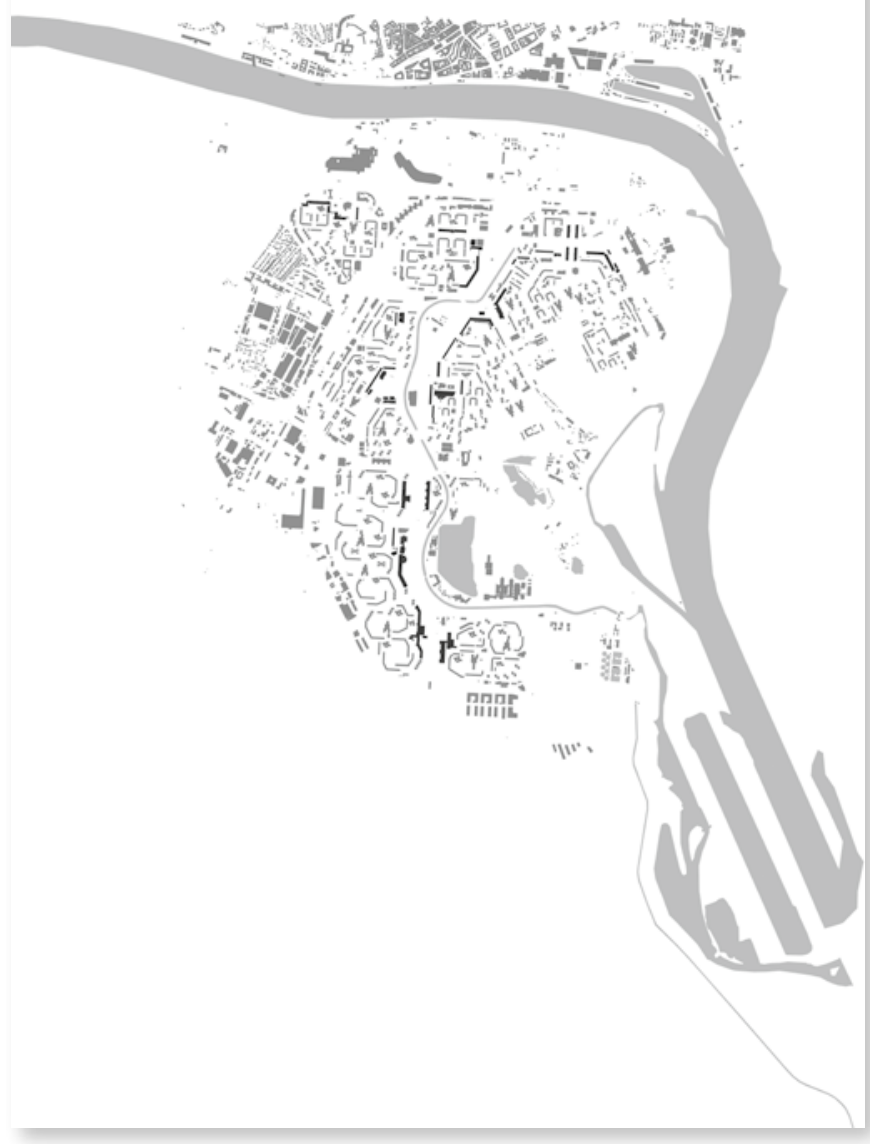

\title{
Community Engagement in
} the Revitalization Process of Elevated Walkways in Petržalka through Prototyping Solutions for Public Spaces

\author{
Zapojenie komunít do procesu \\ revitalizácie verejných priestorov \\ pochôdznych terás v Petržalke
}

Viktor Kasala, Samuel Achberger, Ján Urban

doi https://doi.org/10.31577/archandurb.2021.55.3-4.8

VISUALIZATION OF THE TERRACES IN THE URBAN STRUCTURE OF THE DISTRICT OF PETRŽALKA

SCHÉMA ROZMIETNENIA TERÁS VURBÁNNEJ ŠTRUKTÚRE MESTSKEJ ČASTI

Author Autor: Viktor Kasala
Článok je orientovaný na problematiku verejných priestorov sídlisk. Špecificky autori predstavujú komplikovanú situáciu petržalských terás. Aj ked' obdobné konštrukcie a systémy sa nachádzajú aj v iných častiach mesta, autori sa venujú lokálnemu kontextu Petržalky ako najväčšieho sídliska v strednej Európe, ktorého koncepcia počítala s týmito štruktúrami od počiatku, avšak nedobudovaním prepojení a komplexnej občianskej vybavenosti s nosným systémom sa z pôvodne prepojenej siete týchto terás stali izolované ostrovy.

Pôsobením času, nejasným majetkoprávnym stavom a $\mathrm{z}$ toho vyplývajúcim problémom údržby terasy viditelne degradujú. Terasy ako objekty plnia funkciu verejných priestorov. Okrem toho niektoré poskytujú priestory pre zásobovanie, parkovanie alebo občiansku vybavenost', čomu spravidla zodpovedá aj miera údržby, resp. degradácie terasy.

Mestská čast' v minulosti niekol'kokrát pripravovala projekty rekonštrukcie terás alebo ich častí, avšak ambície týchto projektov siahali vždy len k odstráneniu technických problémov a prinavráteniu priestoru do východiskového stavu. Pozdvihnutie kvality terasy ako verejného priestoru nebolo nikdy súčastou projektov.

Autori v článku predstavujú prípadovú štúdiu, v rámci ktorej, naopak, uprednostnili tvorbu kvalitného verejného priestoru participatívnym spôsobom s priamym zapojením obyvatelov z územia a lokálnych stakeholderov. Primárnou úlohou bolo vytvorit’ priestor, čo by prit’ahoval ludí na trávenie vol'ného času pomocou dočasných zmien, ktorých úlohou je otestovat' možné dlhodobé riešenia.

Autori nemajú snahu pretlačit’ názor, že verejný priestor je dôležitejší ako stavebnotechnický stav terasy a jej bezpečnost' ako objektu, ale chcú poukázat' na potrebu zapojenia obyvatel'ov a stakeholderov do procesu plánovania ešte pred samotnou projekčnou fázou už v rámci strategickej prípravy projektov napríklad využitím participatívnej metódy Placemaking. 

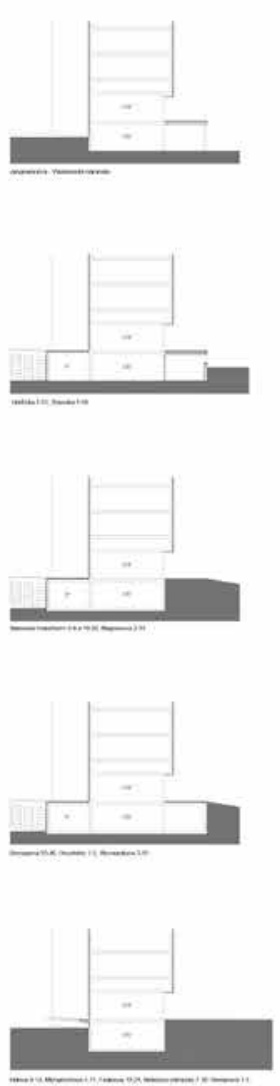
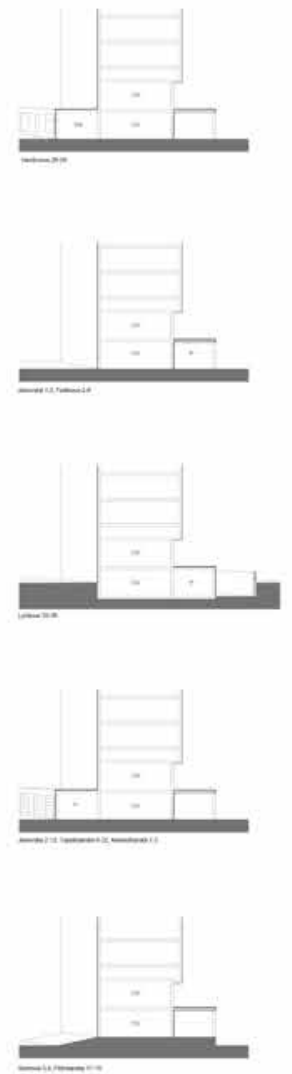
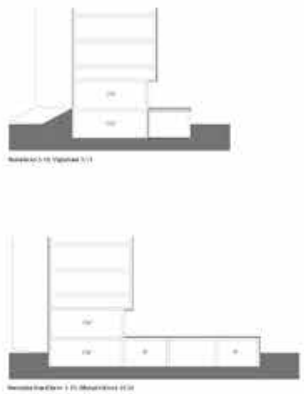
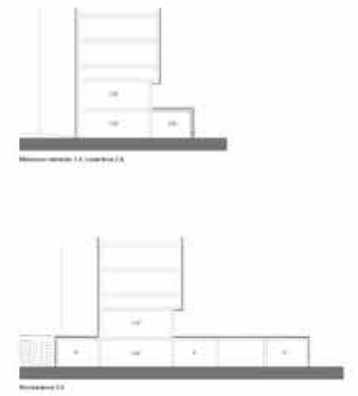

DIFFERENT USE OF THE SPACES UNDER THE TERRACE AND CONNECTION WITH THE LEVEL OF PUBLIC SPACE

TERASY SA ODLIŠUJÚ ICH PREPOJENÍMS ÚROVŇOU TERÉNU A VYUŽITÍM PRIESTOROV POD TERASOU

Author Autor: Viktor Kasala

\section{Introduction}

The Socialist era in Slovakia was responsible for the rapid formation of urban environments and architecture around the whole country, and the context of Bratislava was no different. The largest and most populous of such planned neighborhoods is the district of Petržalka, through which the city finally expanded to the right bank of the Danube in the 1970s.

Immediately after WWII, new neighborhoods mostly reflected, in terms of their composition, the final stage of the avant-garde functionalist traditions, with construction appearing far from the city center next to the industrial areas without connection to public facilities. On the other hand, in the era of the building of the Ružinov, Karlova Ves or Petržalka housing estates, public facilities were strongly integrated in the design with direct connection to complex facilities and high-quality public spaces, according to the assumed needs designed as boulevards, squares and parks.

The designers aimed at formulating an urban environment free of "undesirable" spontaneity. Simultaneously, the era was marked more generally by the search for the form of the polyfunctional urban building. ${ }^{1}$

In combination with the concept of vertical segregation, the new type of public spaces extended the portfolio of panel housing neighborhoods to include a new element - elevated terraces. The failure to complete the concept, strengthened by the post-1989 political and economic transition of republic and the unclear privatization of real estate, turned these lively pathways into a complicated problem facing the city district. Even today, we cannot find a practical solution because the problem is much more complex than merely the degradation of the physical structure.

In many ways, this conundrum is the starting point for this paper. The aim of the authors is to propose a complex perspective on the topic of the terrace structures in Petržalka, to identify the reasons giving rise to their present condition, explore projects and approaches of the municipality so far, and briefly explain two processes of placemaking that focus on their revitalization involving the local community as opposed to the top-down projects of the city district office.

Both case studies are a part of a wider research project on the topic of the revitalization of the terrace structures in Petržalka, led by Viktor Kasala under the supervision of Prof. Ing. arch. L'ubica Vitková, PhD. Additionally, both case studies were organized by the local NGO krasy terasy ${ }^{2}$ (the present authors Viktor Kasala and Ján Urban are also members).

\section{Importance of the Topic}

As is written in The New Urban Agenda3, "Citizens' participation is essential to achieve more strict public scrutiny and to ensure a sustainable way of developing our cities." The Agenda assigns great potential to public spaces, a goal indicating a major shift compared with the previous Urban Agendas from twenty and forty years ago. Moreover, the European Urban Agenda has, for the first time, ever named public spaces as the "most important topic" for our cities. 

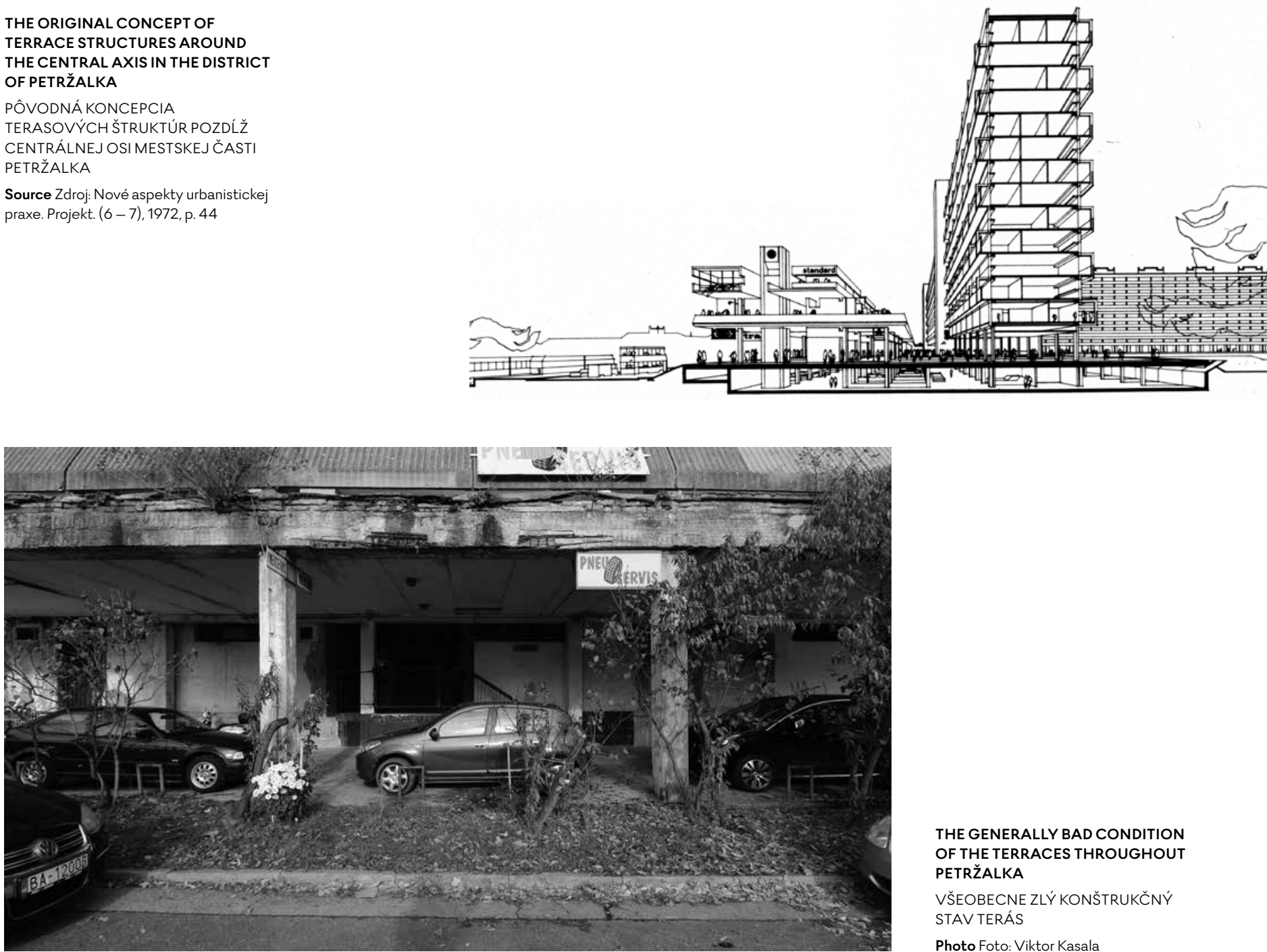

THE GENERALLY BAD CONDITION OF THE TERRACES THROUGHOUT PETRŽALKA

VŠEOBECNE ZLÝ KONŠTRUKČNÝ STAV TERÁS

Photo Foto: Viktor Kasala

Approximately $70 \%$ of the inhabitants of Bratislava currently live in panel housing neighborhoods. Such a high percentage indicates the crucial importance of these areas for sustainable development and social stability of the city of Bratislava. Inspirational examples in developing knowledge on the topic of panel housing neighborhoods include the current project in Karlova Ves called "DELIVER" change resilience, the EU GUGLE ${ }^{5}$ project which resulted in the first almost zero-energy-consumption panel building in Slovakia, or the program of Czech Technical University in Prague with the project "Housing Estates, What's Next?" focused on searching for a methodology towards the further development of these estates with a focus on social, environmental, economic and sustainable urban development aspects.

\section{Description of the Point of Interest; Description of the Terraces}

For the purposes of this paper, the word "terrace" represents a specific type of elevated walkway construction built right next to the linear 12- to 14-story polyfunctional buildings, in certain instances connecting several buildings in the form of a sidewalk or wide plateau. As a structure, the terraces exist in several variants and their combinations found in the site:

a) covering the opened supply zone along the building and entrances to the block of flats,

b) forming a structure of individual or collective garages,

c) covering a tunnel for supplying the spaces for public amenities,

d) serving as a secondary lower level of the active ground floor with public amenities.

Various combinations of use of the spaces under the terrace and different contexts make every structure specific.

The terrace level is always connected with the commercial spaces. Originally, the design plans expected gradual development of the public facilities in the central axis area in immediate connection with the terraces. ${ }^{7}$ Nevertheless, this complex development never took place.

After 1989, public facilities such as shopping centres, office buildings and new residential developments started to grow on the outskirts of the district, most significantly at the turn of the 
frontages with solid masonry, both of which also contribute to the degradation of the terrace spaces.

4. Absence of strategic documents - At present, there is no clear strategy or even any definite idea on what to do with the terraces, or how they could or should be developed to support their role in urban structure. Unfortunately, even the extant strategy for pedestrian traffic, as the document most closely related to this topic, does not even mention any principle or solution for them. This finding is indicative of the previous structural problems in urban governance, "which often almost completely lacked any complex strategy or vision of urban development, partly due to the neoliberal condition of cities and their weak regulatory powers", but also due to untransparent tactics of governance where small group of elites benefitted from the defective system. ${ }^{12}$ Speaking to the latter, Sýkora and Bouzarovski ${ }^{13}$ underscore the role of politicians, under the new economic regime, in undermining the regulatory role of planners, turning instead to developers whose projects offered a whole new image of the city (2012).

\section{Activities of the Municipality and District Administration}

This convoluted nexus of problems, ranging from shifting responsibilities for maintenance and economic forces to changing societal attitudes, has led to the current state of the terraces being "spaces for no one". Based on research into local media, there were a few attempts by the Petržalka district office toward reconstruction of the terraces (archive of Petržalské noviny 2008 2019). ${ }^{14}$ Unfortunately, public bodies are able to invest only in terraces in their ownership or terraces with life-threatening construction status. Still worse, all these attempts aimed merely to reach previous condition. No innovation, no reflection of climate change, no additional value of the public space has been realized.

Judging from the archive of local newspapers and field research, the usual method of reconstruction was most often targeting problems with water penetration. After this reconstruction, the terraces were once again flat grey surfaces, with sometimes even worse conditions for pedestrian movement and lacking aesthetic quality.

With reference to a personal discussion with the former head of the city district, deputy mayor Michal Radosa, in the past there were also Public-Private Partnership projects with owners of the terrace on Mánesovo Square, involving complete reconstruction of the terrace with 50 - 50 financing. Nevertheless, the project was halted already in the planning stage, when the private owners abandoned this co-operation because they found a cheaper construction company than the one that won the public tender.

Though now trying to find solutions, the municipality has unfortunately had little success because of legal complications and limited competences. In combination with the low interest of the residents, the limited financial capabilities of the owners of the terraces, the high level of needed investment or the problems and specifications connected with public procurement all limit the possible solutions toward resolution this problem.

\section{Participatory Planning and Placemaking}

As a partial response for this long-time problem of the neighborhood, we briefly present two revitalization case studies undertaken in 2018 and 2020 in Petržalka led by the local NGO krasy terasy. Instead of technical reconstruction, their aim was to experiment with the potential for reinstating the terraces as a public space. A particular focus here was on community, regarded simply as the group of people connected to the terraces through geographic proximity.

Active community participation in urban planning processes is still quite a novel practice in the context of Bratislava, as well as Slovakia as a whole. This situation becomes particularly apparent when compared to the evolution of social architectures in European countries that were not a part of the socialist block. As Grešáková et al. note, "in the West, unlike in Czechoslovakia, the year 1968 marks a symbolic victory of the struggles for alternatives, the legacy of which is felt until today". ${ }^{15}$ In Slovakia, such a tradition of searching for alternatives and the related turning to the generative potential of public participation in planning processes was not desirable during the decades of repression, nor in the years that followed (ibid). Today, the standards for participatory planning in Slovakia are still in the course of formation, as are the general attitudes towards it among all the professionals involved: architects, facilitators, managers, city officials or inhabitants.

Aware of the need for an alternative approach in planning and architecture that would limit the top-down tendencies of architects (which is the occupation of the facilitators), we attempted to incorporate the involved public in the inception and realization of the projects, as well as in its entire process, at least to ensure that the projects themselves truly reflect the needs of local inhabitants

"Placemaking is the process of creating quality places that people want to live, work, play, and learn in". ${ }^{16}$ Similarly, placemaking is concretely the process of collectively reinventing and redesigning of the public spaces, neighborhoods, or districts. As a process, it can have community, political or commercial initiators. As a collective process reduced the pressure on individuals by spreading responsibilities, financial costs or decision making within the group etc.

As both a process and a word, placemaking is closely connected with the organization Project for Public Spaces (PPS ${ }^{17}$ led by Fred Kent, a student of William H. Whyte. For decades, PPS shared good practice, supported local communities and advised municipalities on the topic of placemaking, which also stimulated greater interest of researchers about the term and process itself.

Placemaking eventually became a topic of various research aims around the world. We could define four types of placemaking as explained by Professor Wyckoff.

By the term Standard Placemaking, we can explain general concept and process. Subsequently, in more detail, placemaking can be divided into three major categories:

1. Strategic Placemaking - Certain types of Quali-

ty-of-Life improvement. 


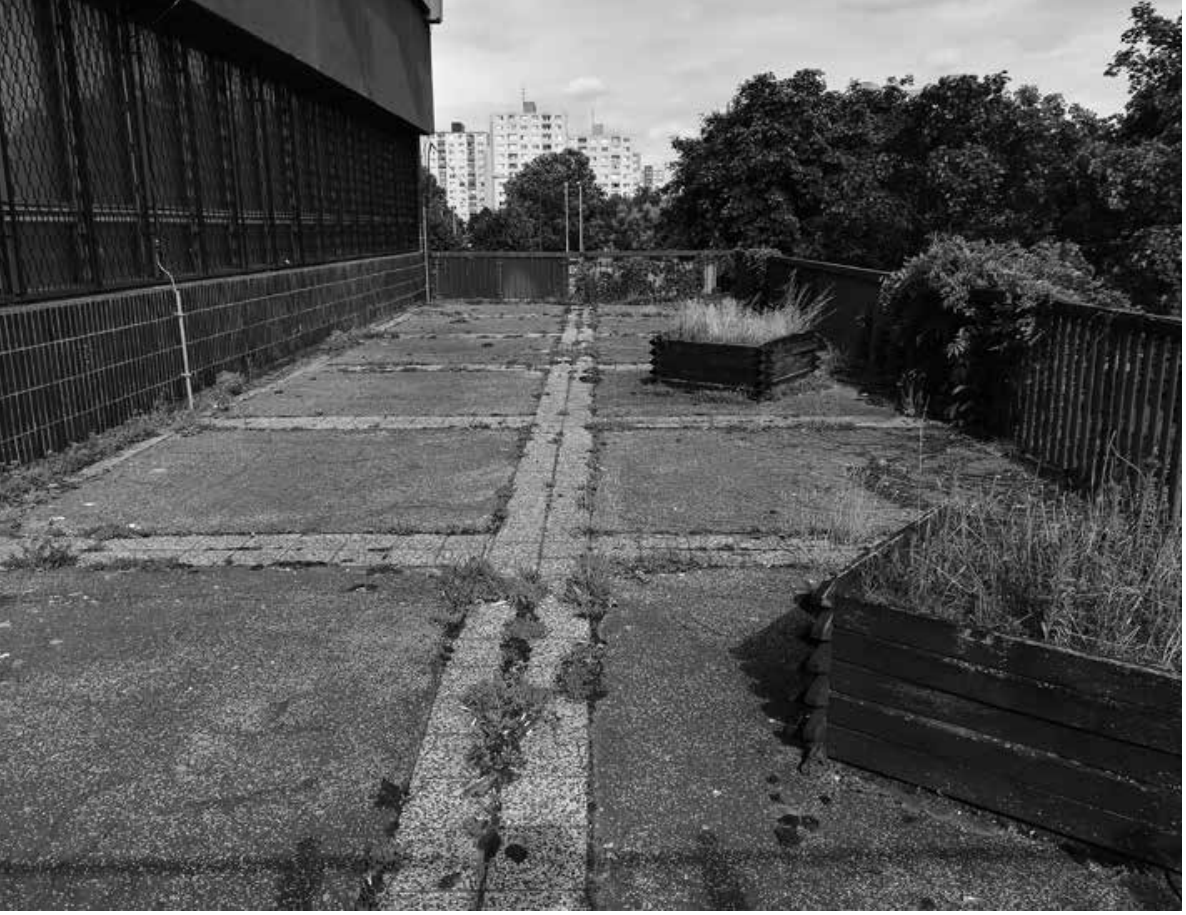

THE SOUTH TERRACE AT

VAVILOVOVA STREET BEFORE THE

REVITALIZATION PROCESS

JUŽNÁ TERASA NA VAVILOVOVEJ

ULICI PRED REVITALIZÁCIOU

Photo Foto: Viktor Kasala

2. Creative Placemaking - Ways to achieve larger or smaller outcomes/benefits or to achieve them sooner.

3. Tactical Placemaking - Ways to try some things out before committing significant money and other resources.

From the beginning as krásy terasy, we based our approach on cooperation and following the characteristics of Placemaking detailed above, aimed to use and test this type of process to shift the thinking of the stakeholders from shifting responsibility from one to another toward collective cooperation on evolving these spaces together in partnership.

The case studies point out opportunities and possible directions, but also the problems and potential threats of using placemaking approaches and participatory processes. We both defend and critically assess the community-based approaches to public space renovation, however temporary, at least until a thorough strategy emerges for development and reconstruction of Petržalka's elevated walkways-terraces.

\section{Methodology}

Both case studies were based on a placemaking approach oriented toward revitalization of public spaces with the involvement of local inhabitants. Our proposal for both terraces reflected the outcomes of previous neighbors' meetings resulted in a certain degree of assignment.

\section{General method of process:}

Step 1 Collective analysis with participants - to discuss actual conditions of the public space

Step 2 Design phase - creative part of architects based on outcomes of the previous step

Step 3 Design approval - presentation of the design to participants

Step 4 Budget collecting - registration for grant schemes
Step 5 Summer brigades - participants physically involved in the work of revitalization

Step 6 Socializing events - final presentation of the revitalized space and its potential

\section{Step 1, Collective analysis with participants}

Both case studies started with collective talks with participants - neighbors of the Mánesovo square and Vavilovova street. During meetings with participants, we conducted walks around the area and terrace, maintaining a discussion on how they perceive public spaces, where they usually going for walks, what kind of atmosphere is missing there or which part they considered already good, in the form of a moderated discussion focused on the quality of public spaces.

In this stage, participatory tools such as Public Presentation, Urban Walk, ${ }^{18}$ Jane's walk ${ }^{19}$ and survey were used.

\section{Step 2, Design phase}

Based on previous analyses, reference pictures showcasing the atmosphere and material solution were presented to the participants to discuss their expectations in greater detail. After this meeting, design proposals prepared by architects were presented to the attendants. From among the ideas of the participants, the architects involved prepared the design reflecting such real-world challenges as heat islands, rainwater collecting and extension of green surfaces.

\section{Step 3, Design approval}

The final discussion was mainly focused on phasing and explanation of the role of the participants and their time possibilities, to make sure they are able to work on the revitalization. In this stage, Saturdays were chosen as the working days. 


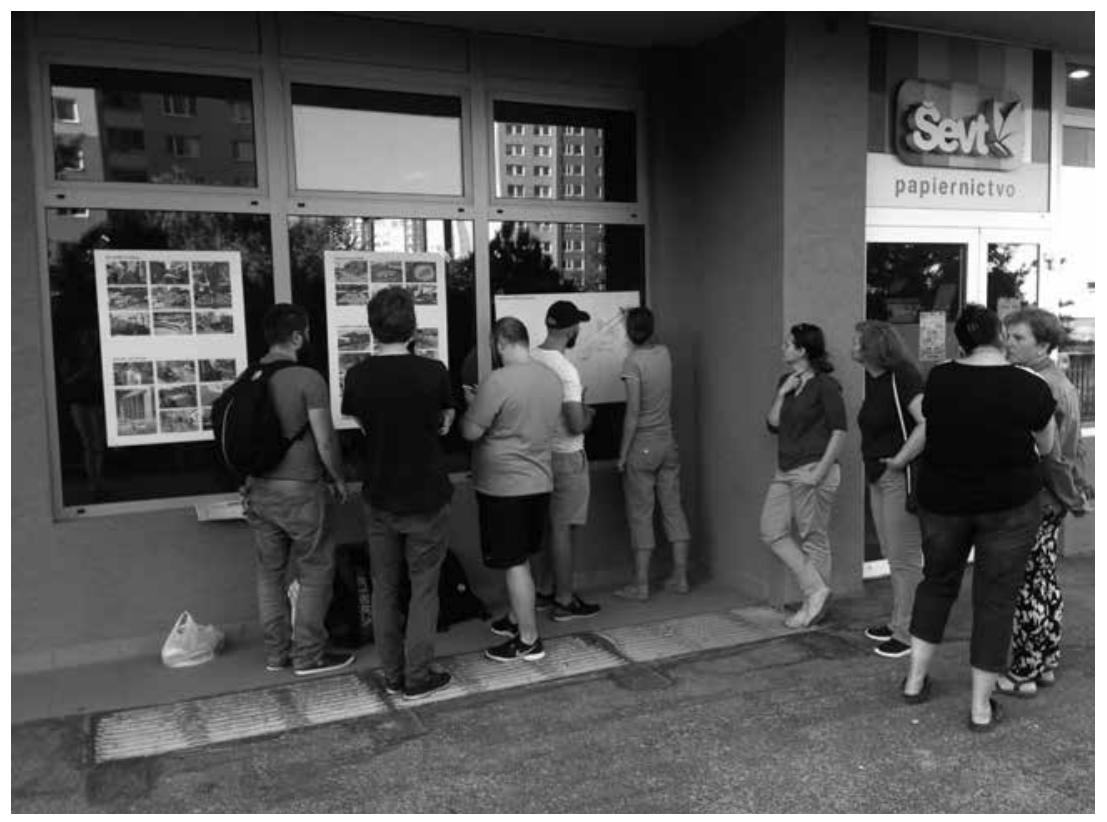

DISCUSSION ABOUT POSSIBLE

SOLUTIONS

STRETNUTIE K MOŽNÝM RIEŠENIAM

REVITALIZÁCIE

Photo Foto: krasy terasy, o. z.

\section{Step 4, Budget collecting}

The budget for the first project was donated by one public grant of 4,800 EUR with $20 \%$ financial participation by the group of he flat owners. The VAVILOVOVA project had a budget of 8,500 EUR supplied by two public grants and the money provided by the local municipal office. In this case, the inhabitants were not asked to contribute financially.

In both projects, we noticed an interesting side-effect in that the interest in the project snowballed as it progressed. In MANES, we received support from the city district, but the other stakeholders helped too. For example, a shop selling sound systems on the ground floor of the terrace supported a community event near the end of the project. From another side of the street, a pub supported the event by providing food and serving drinks. Still more companies and sponsors supported the VAVILOVOVA project, including local city council members who used their annual budgets to help build the pavilion.

\section{Step 5, Summer brigades}

Each second Saturday, we held meetings with neighbors on the terrace with exact tasks and prepared tools and materials. One of the targets of the MANES project was to bring neighbors together to collectively revitalize public space and build relationships to the terrace, to plant the seed of community through their cooperation.

In the VAVILOVOVA 2020 project, though we aimed to attract neighbors from the building above the terrace, we failed in this target, yet on the other hand attracted organizations running their businesses on the ground level and thus connected with the terrace. This shift also significantly changed the process and aims that we wanted to achieve. Besides the physical changes, we intended to connect these institutions and mutually explain their shared interests and goals. In Vavilovova street, we connected with the Library and Centre Svetielko.

\section{Step 6, Socializing events}

Public events in both projects have proven to be very important points. In the MANES project, they helped to motivate people and show them the possibilities that they could not see before the opening party, and to stimulate neighbors and participants to get to know each other. These kinds of events did not continue to take place after the end of the first phase of MANES project, yet nonetheless other types of activities occur on the terrace. As mentioned before, the first signs are of occasional children playing.

One positive outcome in the case of organization was setting up a group chat connecting several neighbors who currently are engaged in taking care of the flowerpots. It is questionable as to how sustainable these activities are and when it is the right time for organizers to leave the group for it to keep evolving in its own way. Nevertheless, even three years later, the flowerpots are well maintained, indicative that someone still does take care of them.

In the VAVILOVOVA project, it was the string quartet concert under the terrace that served as a "mind-changing" experience for the audience, uncovering the hidden potential of the space. Socializing events in the project for Vavilovova street were included as specific days for each parterre.

\section{Discussion}

Both case studies were based on a participatory process and a realization of tactical placemaking interventions on terraces. Both were led by the same group of volunteering architects. The aim was to test easy and cheap self-made tactical (temporary, easy, reversible) interventions and through them to define new solutions that could predict sustainable permanent changes. At the same time, through establishing partnerships with local organizations, the projects have the potential to create a new type of social-cultural spot on the terraces for residents and the general public. 


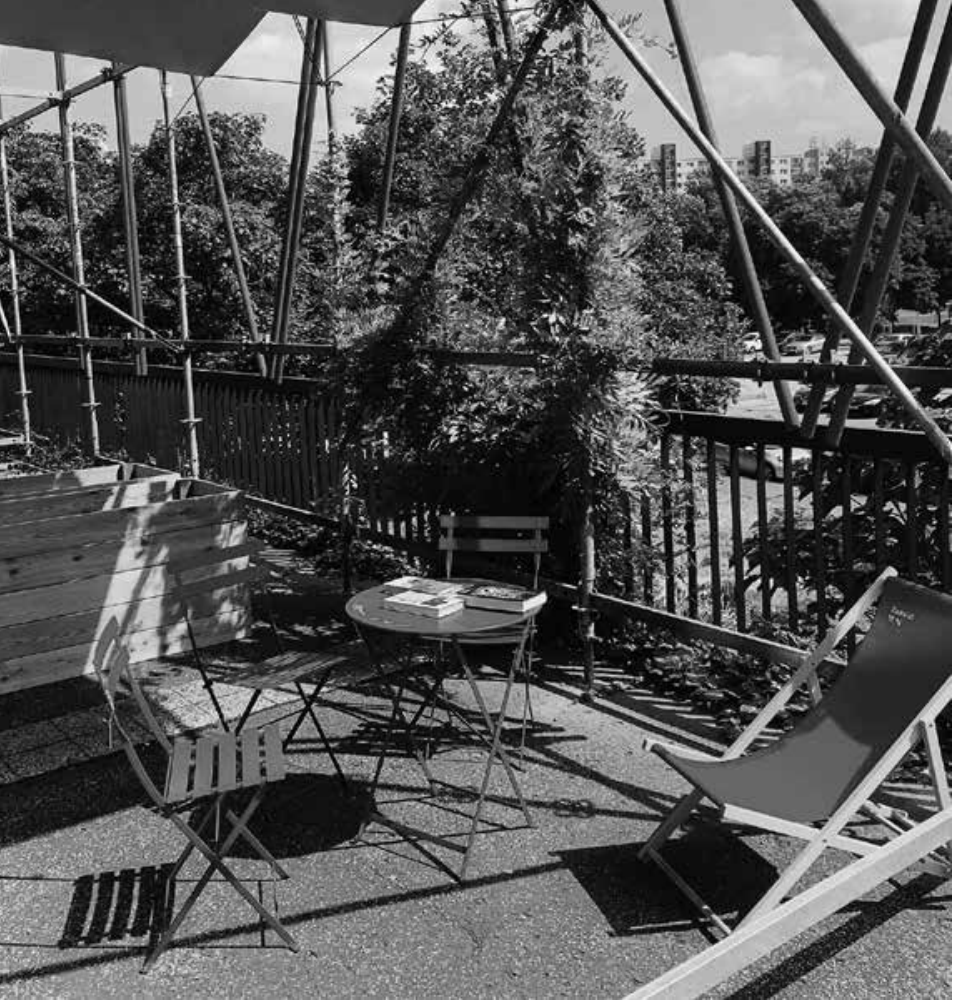

In comparison with the earlier activities of the city district office, these processes were people-oriented with a focus on improvement of these terraces as high-quality public spaces, instead of specifically addressing technical problems of construction.

Without any doubt, it is clear that no single approach will solve the complex problem of terraces alone, but that a complex process combining both approaches is needed for each terrace. Each one is specific, and these differences must be reflected in the design process. Moreover, the differences within the presented case studies have a significant impact on the process, design, and sustainability of the interventions.

If we were to make a brief comparison of our case studies and define the main differences between them, the findings would be:

1. Type of the organization of the flat owners. In Mánesovo square, the residents are managing their building as a group of owners, in the form of a collective of flat owners with their chairman and council. That fact in itself would indicate a stronger interest in the issues connected to their house. On the other hand, the flat owners at Vavilovova street have a contract with the management company "Bytové družstvo Petržalka" to manage their building.

2. Different serviceability of the terraces. We need also to compare the different use and service of both terraces. At MANES, the main entrances are situated on the terrace level, so the inhabitants have to cross this space on their way home. On the other hand, the terrace on Vavilovova street is used only by people passing through the terrace and by the visitors to the library visitors or the Svetielko centre. The entrances for inhabitants are situated below the terrace, hence residents are not inherently involved in the life of this space, which also led to its poor condition and disorderly surface in the first place.
LOCAL PARTNERS TAKING CARE

OF THE SPACES

LOKÁLNI PARTNERI PREVÁDZKUJÚ

REVITALIZOVANÝ PRIESTOR

Photo Foto: Metropolitan Institute

of Bratislava

3. Ownership of the terrace. The terrace at Mánesovo square is owned by the private owners of the shopping spaces below the terrace. The same situation applies at the north part of the terrace at Vavilovova, yet the terrace on the south side of Vavilovova has no owner.

4. In both projects, the inhabitants were invited to join in each activity by a poster campaign. Additionally, in the project at Vavilovova street, people from all around Petržalka were invited by events shared through the social sites of partnering organizations.

We should mention also often-debated issue of the role of the architect. In Western countries, there are specialists for participatory planning and facilitation who manage the processes and employ a variety of tools to collect the data, process them, and prepare the report for the architect who plays only a partial role in the process, and by extension helping to propose the solutions for a particular issue. However, the architect on the other hand is the participant who has combined knowledge from several professions, and is thus able to explain the decisions and choose solutions, despite the current trends of highly accessible wide-ranging knowledge on the internet. The presence of the architect in community participatory meetings might help to reveal the importance of each problem and finally, it will keep him or her connected to reality of ordinary life of residents. If she or he should design good public spaces or buildings, the understanding of the lifestyles and needs of its actual and future residents is essential.

\section{Conclusions}

The described activities were processes aimed at the testing various types of activities, various participants and various intensity and role of their involvement, or timing in comparison of former attempts of the city district office in looking for a solution for the terraces in Petržalka. The main test was the use of a bottom-up approach in the physical change of the public space on the terrace constructions, with the intention of building a community in the district with neighbors or other stakeholders who have a relation to the locality. These tests have proven that neighbors or local stakeholders in an organized process are able to improve the conditions of their respective areas. They can name the problems, describe the real context of the area based on their expertise on it and with professional support, can change the areas themselves as well.

In the words of Zygmunt Baumann: ... you architects and urbanists should not consider yourself as managers of humans, you should see yourself as liberators, animators, inspirers who inspire people to do interesting things (themselves) and who help develop their potential which otherwise would be stifled. 
The main recommendation of the authors is to emphasize the importance of not merely pushing this problem out of sight even if it appears too complicated to grasp. As vitally crucial, we see the need to draw attention to this problem in strategic documents and to propose solutions for future development, even more, to open the discussion with local stakeholders and not just wait for the active citizens and developers. Quite regrettably we see this perspective on this problem lacking already in two studies of pedestrian traffic - Háje (2017, IN-Architects) ${ }^{20}$ and Dvory (2018, IN Architects). ${ }^{21}$ Future studies need to consider these spaces as a special kind of public space and should propose specific solutions or visions of how they should develop further, based on complex socio-economical and spatial analysis. On the other hand, these terraces are separate constructions built next to buildings with two stories of nonresidential functions. Based on this idea, an urban study of the central district axis is proposed as a possible solution to deconstruct the terrace and reanimate this parterre for the entire two stories of public facilities spaces. ${ }^{22}$
Meanwhile, in 2020 the City of Bratislava launched a call for financial support for reconstruction of the terraces and investing 200,000 EUR annually with maximum 50\% support for selected projects. A good sign is that one of the grant conditions is the expectation that the selected projects will create high quality public spaces.

Deeper participation with residents is an effective means for innovating municipal governance in Slovakia. Such projects can be a highly worthwhile testing environment before executing participatory tools in bigger projects. These processes open a new perspective for rethinking policies and investments of city officials and, in the opposite direction, can motivate inhabitants to increase their interest in public life and events in the city and local politics. To conclude, community building might be an answer to today's challenges of panel housing settlements. While the sense of community is difficult to create, it is important to support the real homelike atmosphere of the neighborhood and allow people to remake their immediate surroundings to stimulate a more positive relationship to the public space.
ING. ARCH. VIKTOR KASALA

ÚSTAV URBANIZMU A ÚZEMNÉHO PLÁNOVANIA, FAD STU V BRATISLAVE

Námestie slobody 19

81245 Bratislava

Slovakia

kasala.viktor@gmail.com

\section{SAMUEL ACHBERGER, MSC}

METROPOLITNÝ INŠTITÚT BRATISLAVY

Ventúrska 22

81101 Bratislava

Slovakia

samuel.achberger@mib.sk

\section{ING. ARCH. JÁN URBAN}

ÚSTAV URBANIZMU A ÚZEMNÉHO

PLÁNOVANIA, FAD STU V BRATISLAVE

Námestie slobody 19

81245 Bratislava

Slovakia

jan.zeal@gmail.com
1 JANÁČ, Karol and ŠTEIS, Rudolf, 1980. Tvorba sídelných štruktúr a systémov - správa pre záverečnú oponentúru. Bratislava: Ústav stavebníctva a architektúry SAV.

2 krasy terasy o. z. - members: Lucia Adameková, Ján Urban and Viktor Kasala.

3 United Nations, New Urban Agenda (A/RES/71/256), United Nations, 2017.

4 DELIVER: DEveloping resilient, low-carbon and more LIVable urban Residential areas - housing estates as lively places resistant to climate change.

5 EU-GUGLE is the abbreviation for European cities as Green Urban Gate towards Leadership in Sustainable Energy

6 KOHOUT, Michal, TIVHÝ, David, TITTL, Filip, KUBÁNKOVÁ, Jana and DOLEŽALOVÁ, Šárka, 2016. Sídlište, jak dál? Praha: České vysoké učení technické v Praze, Fakulta architektury, Ústav nauky o budovách.

7 To find out more about the concept of the Petržalka district see: Mestský sektor Petržalka. Projekt. (158 - 159), 1972, pp. $23-45$

8 In only one year in 200o, three new shopping centres were built (TESCO, DANUBIA and TERNO) right next to each other in the western part of Petržalka. The following year, the shopping centre AUPARK opened as well. ŽALMAN, Peter, 2007. Architektonický atlas Bratislava 1970 - 2006. Bratislava, pp. 5.1 - 5.13.
9 TSENKOVA, Sasha, 2006. Beyond Transitions: Understanding Urban Change in Post-Socialist Cities. In: The Urban Mosaic of Post-Socialist Europe. Heidelberg: Physica-Verlag.

10 Ing. arch. M. Malík, Technická správa, architektúra Objekt: D-IV-1/c pristavaná vybavenost'.

11 MAROZASA, Martynas, 2015 Socialist City in a Post-Socialist Condition: The History of Transition. ZARCH. 5 p. 1; SÝKORA, Luděk, 2009. Post-Socialist Cities. In: Rob, $\mathrm{K}$. and Nigel, T. (eds.). International Encyclopedia of Human Geography. Oxford: Elsevier, pp. $387-395$.

12 ACHBERGER, S., 2020. Quick Wins': Temporary Spatial Intervention as Used by Urban Planners at the Metropolitan Institute of Bratislava. [Masters Dissertation]. University of Oxford, p. 17.

13 SÝKORA, Luděk and BOUZAROVSKI, Stefan, 2012. Multiple Transformations: Conceptualizing the Post-Communist Urban Transition. Urban Studies. 49(1), pp 43 - 60.

14 Archive of Petržalské noviny, accessible at Miestna knižnica Petržalka, Vavilovova 26.

15 GREŠÁKOVÁ, Lýdia, TABAČKOVÁ, Zuzana and RÉVÉZSOVÁ, Zuzana, 2020. Mapping with Care as an Outline for Post-neoliberal Architecture Methodologies - Tools of the "Never-Never School". Architektúra o Urbanizmus. 54(1-2), p. 9.
16 WYCKOFF, Mark A., 2014. Definition of Placemaking: Four Different Types, MSU Land Policy Institute. [online] 2014 [Accessed 20 Nov. 2021]. Available at: https://www.cnu.org/publicsquare/ four-types-placemaking

17 More information about organistion and concept. Available at: https:// www.pps.org/category/placemaking

18 More about the method Urban Walk. Available at: https://habitat3. org/documents-and-archive/media-archive/toolkits/toolkit-for-urban-walk/

19 More about the method Jane's Walk. [online] 2017 [Accessed 2o Nov. 2021], available at: https:// janeswalk.org/

20 Petržalka - Háje, koncepcia pešieho pohybu. 2017. Autori štúdie: Igor Hianik, Nikola Winková, René Majerník, Karin Tajtiová and Marián Šipoš. [online] 2017 [Accessed 2o Nov. 2021], https:// www.petrzalka.sk/wp-content/uploads/2017/10/o6_Studia_pesieho_pohybu_Haje.pdf

21 Petržalka - Dvory, koncepcia pešieho pohybu. 2017. Autori štúdie: Igor Hianik, Nikola Winková, Marián Šipoš. [online] 2017 [Accessed 20 Nov. 2021], available at: https:// www.petrzalka.sk/wp-content/ uploads/2017/o6/2018_03_Dvory_ Navrh200o_IN-ARCHITEKTI.pdf

22 KOVÁČ, Bohumil at al., 2019. Urbanistická štúdia Centrálna rozvojová os Petržalky, koncepty riešenia. p. 97 [online] 2019 [Accessed 20 Nov. 2021]. Available at: https://bratislava.blob. core.windows.net 